\title{
Infiltrating gastric adenocarcinoma with disseminated osteoblastic metastases
}

\section{Adenocarcinoma gástrico infiltrante con metástasis osteoblásticas diseminadas}

\author{
V.M. Santos ${ }^{1,2}$, T.A. Vieira ${ }^{2}$, C.S. Marinho ${ }^{2}$, T.P. Loures ${ }^{2}$, B.B.V. Brandao ${ }^{2}$, R.N. Botan ${ }^{3}$
}

\begin{abstract}
We report the case of a man with a diagnosis of invasive gastric adenocarcinoma associated with scattered osteoblastic metastases. This 65 -year-old patient was admitted with nausea, vomiting and abdominal pain, in addition to loss of weight (13 Kg in 3 months). Upper digestive endoscopy revealed extensive infiltrating changes in the body of the stomach, and histopathologic data confirmed the diagnosis of a Borrmann IV gastric adenocarcinoma. Complementary exams were indicative of a gastric cancer with bone metastases, characterized by disseminated osteoblastic images of the scintigraphy of the skeleton. Palliative chemotherapy was the treatment of first choice. High serum levels of CA 19-9, CEA and alkaline phosphatase can constitute useful indicative tools of this challenging condition. Images from a scintigraphy study of the skeleton can characterize the type and extension of bone metastases. The aim of this case study is to report a case of a very uncommon condition, considering that disseminated osteoblastic metastases rarely develop in this kind of tumor.
\end{abstract}

Key words. Adenocarcinoma. Bone metastasis. Gastric tumor.

\section{RESUMEN}

Presentamos un caso de adenocarcinoma gástrico infiltrante asociado con metástasis osteoblásticas diseminadas. Un paciente de 65 años ingresó con náuseas, vómitos y dolor abdominal asociados con pérdida de peso ( $13 \mathrm{Kg}$ en 3 meses). La endoscopia digestiva objetivó extensas alteraciones infiltrativas del cuerpo gástrico y los datos histopatológicos confirmaron el diagnóstico de adenocarcinoma gástrico Borrmann IV. Exámenes complementarios fueran indicativos de cáncer gástrico con metástasis óseas, caracterizadas por imágenes osteoblásticas diseminadas de la cintilografía del esqueleto. Se le administró quimioterapia paliativa como primera opción. Se elevó CA 19-9, CEA y apareció fosfatasis alcalina en el suero un indicador útil del diagnóstico. La extensión y el tipo de metástasis óseas pueden ser imágenes de cintilografías del esqueleto. Este caso tiene como objetivo describir la presencia de metástasis osteoblásticas diseminadas que raramente son producidas por este tipo de tumor.

Palabras clave. Adenocarcinoma. Metástasis óseas. Tumor gástrico.
1. Catholic University Medical Course. BrasíliaDF. Brazil.

2. Internal Medicine Department of Armed Forces Hospital. Brasília-DF. Brazil.

3. Oncology Division of Armed Forces Hospital. Brasília-DF. Brazil.

Recepción: 27 de junio de 2012

Aceptación provisional: 18 de octubre de 2012

Aceptación definitiva: 30 de octubre de 2012

\section{Correspondencia:}

Vitorino Modesto dos Santos

Armed Forces Hospital

Estrada do Contorno do Bosque, $\mathrm{s} / \mathrm{n}$

Cruzeiro Novo

70658-900, Brasilia. Brazil

E-mail. vitorinomodestos@gmail.com 


\section{INTRODUCTION}

Since 1995, mortality by cancer has been the leading cause of death among males in Navarre; while the incidence and mortality rates of gastric cancer have decreased $^{1}$ In Spain, estimates and projections about the above mentioned rates for 2012 are indicative of a downward tenden$\mathrm{cy}^{2}$ Clinically unsuspected gastric adenocarcinoma has been reported in young and old individuals, with diagnosis established exclusively through autopsy studies ${ }^{3}$ Paraneoplastic phenomena and bone marrow implants can precede the diagnosis, which may be confirmed in advanced stage $^{3-5}$. Worth of note, the "oldest old" population is growing both in industrialized and developing countries; therefore, one should consider the possibility of further increase in malignancy rates $^{1,2}$ It is estimated that near $60 \%$ of people with cancer will have bone metastases, which frequently are not demonstrated during their life; fact that poses difficulties to establish the real incidence $^{4}$ Bone metastasis is most frequently due to cancers from prostate, breast, kidney, lung and thyroid ${ }^{4}$ Autopsy studies describe skeletal metastases in only $5 \%$ of patients with gastrointestinal cancers, and osteoblastic implants of primary gastric cancer are considered a very uncommon finding ${ }^{4}$ The objective of this case study is to report an advanced gastric cancer associated with disseminated osteoblastic metastases, a probably under recognized and under reported condition.

\section{CASE REPORT}

A 65-year-old man with arterial hypertension and diabetes mellitus was admitted because of inappetence and weight loss (13 Kg in 3 months), associated with nausea, vomiting and epigastric pain for 15 days. He denied alcoholism and tobacco smoking. Physical examination showed BMI of $24.2 \mathrm{~kg} / \mathrm{m}^{2}$ and pale mucosa. No visceromegaly nor lymph node enlargement were observed. Prostate examination revealed a fibroelastic organ with $30 \mathrm{~g}$ of estimated weight and absence of nodules. Upper digestive endoscopy showed extensive changes on the gastric body, compatible with diffuse infiltration by a highly advanced gastric adenocarcinoma - plastic linitis
(Fig. 1A). Histopathology study of biopsy sample revealed a diffuse pattern adenocarcinoma (Fig. 1B). Laboratory tests and imaging studies were performed. Hemoglobin: 13.1g/dl, hematocrite: 39.9\%, MCV: 79fl, MCH: 33\%, leukocytes: 8,581/ $\mathrm{mm}^{3}$, platelets: $423,000 / \mathrm{mm}^{3}$, glucose: $232 \mathrm{mg} /$ dl, calcium: $9.1 \mathrm{mg} / \mathrm{dl}$, sodium: $140 \mathrm{mmol} / \mathrm{dl}$, potassium: $3.8 \mathrm{mmol} / \mathrm{l}$, urea: $13.8 \mathrm{mg} / \mathrm{dl}$, creatinine: $0.7 \mathrm{mg} / \mathrm{dl}$, ALT: $13 \mathrm{U} / \mathrm{L}$, AST: $9.6 \mathrm{U} / \mathrm{L}$, alkaline phosfatase: $138 \mathrm{U} / \mathrm{L}$, albumin: $3.33 \mathrm{~g} / \mathrm{dl}$, total PSA: $0.787 \mathrm{ng} / \mathrm{ml}$, free PSA: $0.104 \mathrm{ng} / \mathrm{dl}$, CA 19-9: $385.6 \mathrm{U} / \mathrm{ml}$, and CEA: $14.1 \mathrm{ng} / \mathrm{ml}$. CT images with contrast of abdomen revealed multiple osteoblastic implants in vertebral bodies (Fig. 1C) and in pelvic bones. Scintigraphy showed multiple focal hypercaptations on the axial skeleton, and proximal thirds of right humerus and left femur, with features of osteoblastic metastases (Fig. 2). Further investigations about differential diagnosis included routine tumor markers, and specific biochemical determinations related to neuroendocrine tumors, in addition to imaging studies by PET/ CT of the thorax and the head, which revealed unremarkable findings. With diagnosis of unresectable gastric adenocarcinoma, the patient underwent a palliative docetaxel + 5-fluorouracil + cisplatin (DCF) combination chemotherapy and, after hospital discharge, he was referred to regular outpatient surveillance at the Oncology Division.

\section{DISCUSSION}

The incidence of gastric cancer is lowering in industrialized countries, but remains elevated in developing regions, with a higher prevalence amongst males ${ }^{5,6}$ Extension of disease to the adjacent organs constitutes the most common way of this tumor dissemination. Lymphatic metastases first occur to regional and latter to the distant lymph nodes; peritoneal carcinomatosis is the most common site of distant metastasis, followed by the liver, lungs and bones ${ }^{5}$ Bone metastases are found between $1 \%$ and $20 \%$ of cancers of the stomach ${ }^{5,7-9}$ and are mainly osteolytic, while osteoblastic implants are considered rare ${ }^{5-10}$ Notwithstanding, an exceeding rare case of osteoblastic metastases was described in an early gastric cancer - confined to the mucosa and submucosa, which evolved to death 18 months after surgery due to generalized disease ${ }^{10}$ Osteoblastic metastases are characteristic 


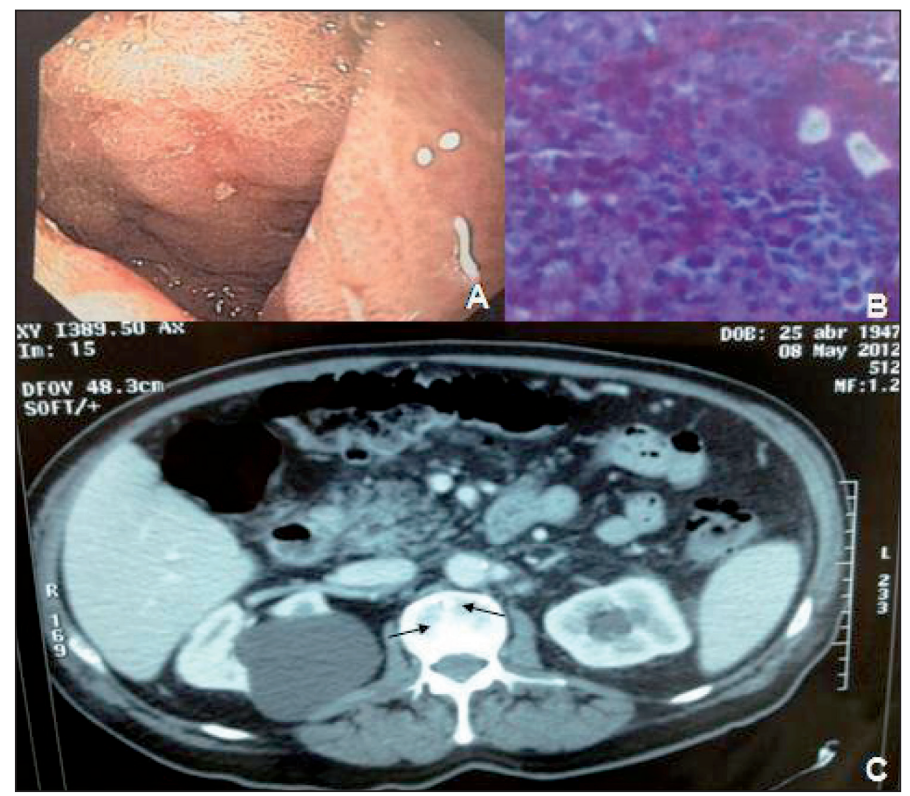

Figure 1. A: Endoscopic features of the infiltrated mucosa at the gastric antral region; B: Photomicrography of histopathology finding from gastric biopsy, revealing an adenocarcinoma with diffuse pattern; C: Images of abdominal CT showing osteoblastic changes on the lumbar spine (arrows).

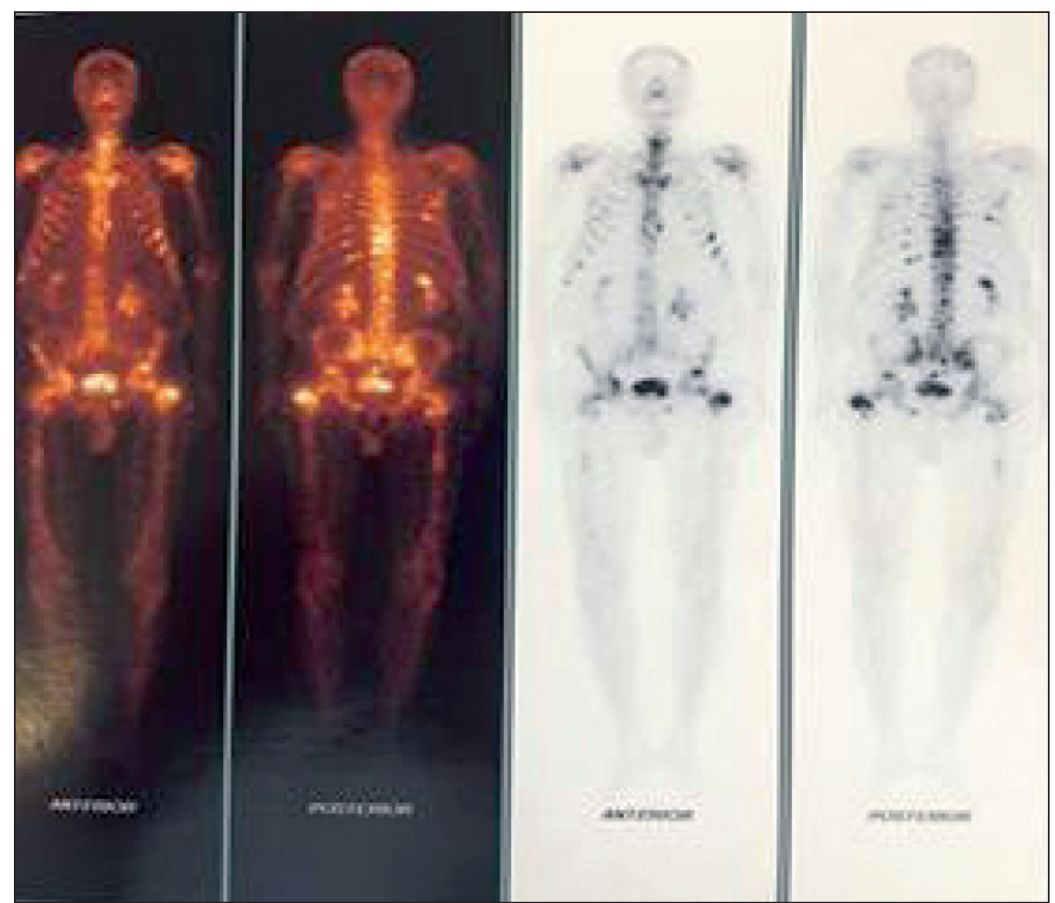

Figure 2. Bone scintigraphy (Tc 99m - MDP, $1110 \mathrm{MBq})$ showing multiple images of focal hypercaptations that affect the axial skeleton, including the proximal thirds of humerus and femur, displaying a pattern of widespread osteoblastic dissemination. 
of prostate cancer, but may occur in other malignancies like carcinoide, gastrinoma, small cell lung cancer, medulloblastoma, astrocytoma, glioblastoma, thymoma, cancers of breast, kidney, thyroid, colon, pancreas, nasopharynx, and urinary bladder, and Hodgkin's lymphoma. Bone metastases may be demonstrated by images of CT, magnetic nuclear resonance, and scintigraphy ${ }^{6,7}$ The diagnosis of fourth Borrmann type ${ }^{8}$ also designated scirrhous gastric carcinoma and linitis plastica was established in this case study. During the staging of the tumor, scattered osteoblastic metastases were detected by CT imaging studies of abdomen, and were further confirmed by the findings from the scintigraphy of skeleton ${ }^{6,7}$ Neither gastrectomy by laparotomy, nor by laparoscopy, were considered good options for treatment of this patient with base on the risk/benefit balance ${ }^{11}$ The choice of DCF as the palliative chemotherapy schedule in the present case was based on the remarkable survival benefit described for patients with advanced adenocarcinoma of the stomach ${ }^{12}$ Bone metastasis associated with gastric cancer is considered a relatively uncommon phenomenon ${ }^{4,5}$ and has been related to poorer prognosis ${ }^{6,9}$ in special if implants occur in multiple areas $^{6,8,9}$ Asymptomatic bone implants occur in up to $20 \%$ of the patients with gastric cancer, but main symptoms are pain, fractures, and paraplegia ${ }^{9}$ Laboratory tests indicative of gastric cancer with bone metastasis include high serum levels of alkaline phosfatase, CA 19-9 and CEA ${ }^{6-9}$ The data (normal range in parenthesis) in our patient were 138 (40-130) U/L, 385.6 (s 34) $\mathrm{U} / \mathrm{ml}$, and $14(\leq 5) \mathrm{ng} / \mathrm{ml})$, respectively. Interestingly, a significant relationship was found between the occurrence of lymphatic dissemination of gastric cancer and concomitant bone implants, in addition to a short survival ${ }^{6,13}$ Notably, osteoblastic flares have been reported in patients with advanced gastric cancer submitted to antitumor therapy ${ }^{7}$ however, we detected the implants before the cytotoxic regimen. Major concern was the finding of osteoblastic implants in an old male patient, which raised the initial hypothesis of a primary prostate cancer ${ }^{4,6}$ Nevertheless, he was accurately evaluated by specialists in Urology, and his serum levels of total and free PSA were found within the respective normal ranges. Therefore, the hypothesis of a concomitant prostate cancer was ruled out. Furthermore, no indicative feature of other coexistent malignancy was detected.

The purpose of this report is to enhance the awareness of non specialist physicians about the possible occurrence of osteoblastic metastasis in advanced gastric cancer, emphasizing the levels of alkaline phosfatase, CA 19-9 and CEA as useful tools for clinical suspicion, and the scintigraphy imaging of skeleton for accurate evaluation of the involved bones.

\section{REFERENCES}

1. Ardanaz E, Moreno-Iribas C, Pérez De Rada ME, EzPonda C, Flaristán Y, NavARIDAs N et al. Incidencia y mortalidad por cáncer en Navarra, 1998-2002. Evolución en los últimos 30 años. An Sist Sanit Navar 2007; 30: 245-270.

2. Sánchez MJ, Payer T, De Angelis R, Larrañaga N, Capocaccia R, Martinez $C$ for the CIBERESP Working Group. Cancer incidence and mortality in Spain: estimates and projections for the period 1981-2012. Ann Oncol 2010; 21: iii30-36.

3. Santos VM, Castro ECC, Araújo AC, Reis MA, TEIXEIRA VPA. Budd-Chiari syndrome and unsuspected gastric adenocarcinoma. Medicina (Ribeirão Preto) 2005; 38: 156-160.

4. Maccauro G, Spinelli MS, Mauro S, Perisano C, Graci C, Rosa MA. Physiopathology of spine metastasis. Intern J Surg Oncol 2011; 107969. Epub 2011 Aug 10.

5. Escuissato DL, Ledesma JA, Urban LABD, Liu CB, Reis Filho JS, Oliveira Filho ag et al. Metástase de câncer gástrico simulando neoplasia primária de pulmão - relato de caso e revisão da literatura. Radiol Bras 2002; 35: 121124.

6. АнN JB, HA TK, Kwon SJ. Bone metastasis in gastric cancer patients. J Gastric Cancer 2011; 11: 38-45.

7. Amoroso V, Pittiani F, Grisanti S, Valcamonico F, Simoncini E, Ferrari VD et al. Osteoblastic flare in a patient with advanced gastric cancer after treatment with pemetrexed and 
oxaliplatin: implications for response assessment with RECIST criteria. BMC Cancer 2007; 7: 94.

8. CChung YS, ChoI TY, Ha CY, KIM HM, LLEE KJ, PPARK CH et al. An unusual case of osteoblastic metastasis from gastric carcinoma. Yonsei Med J 2002; 43: 377-380.

9. MARTI J, SAINZ M. Unusual late metastasis from gastric carcinoma. Saudi J Gatroenterol 2011; 17: 423-424.

10. Anagnostopoulos G, Sakorafas GH, Kostopoulos P, Margantinis G, Tsiakos S, Pavlakis G. Early (mucosal) gastric cancer with synchronous osteosclerotic bone metastases: a case report. Eur J Cancer Care (Engl) 2010; 19: 554-557.
11. Ibáñez FJ, Azagra JS, Goergen M, Bordas JM, ALMENDRAL ML, ERRo JM. Cirugía laparoscópica del cáncer gástrico. An Sist Sanit Navar 2005; 28: 21-31.

12. Ben Aharon O, Purim O, Kundel Y, Brenner R, Gordon N, SulKes A et al. The combination of docetaxel, cisplatin, and 5-fluorouracil in advanced gastric cancer: a single-institution experience. Anticancer Drugs. 2012 Jan 10. [Epub ahead of print]

13. Kong JH, Lee J, Yi CA, Park SH, Park JO, Park YS et al. Lung metastases in metastatic gastric cancer: pattern of lung metastases and clinical outcome. Gastric Cancer 2011; Oct 29. [Epub ahead of print] 